\title{
LOW ANTIPLASMODIAL ACTIVITY OF ALKALOIDS AND AMIDES FROM THE STEM BARK OF ZANTHOXYLUM RUBESCENS (RUTACEAE)
}

\author{
PENALI L.*, MULHOLLAND D.A. **,*****, TANO K.D.", CHEPLOGOI P.K.**,**** \\ \& RANDRIANARIVELOJOSIA M.*******
}

\section{Summary:}

The stem bark of Zanthoxylum rubescens (syn. Fagara rubescens) is used for treating fevers associated with malaria in the Ivory Coast. Three alkaloids: N-nornitidine, 7,9-dimethoxy-2,3methylenedioxybenzophenanthridine, and bis $[6-15,6-$ lemairamide, were isolated from the stem bark of this plant. These compounds were screened in vitro against the chloroquine-sensitive P. falciparum. N-nornitidine was found to be inactive. 7,9dimethoxy-2,3-methylenedioxybenzophenanthridine, lemairamide and zanthomamide showed weak activity with average $I_{50}$ values ranging from 45.6 $\mathrm{M}$ to $149.9 \mu \mathrm{M}$. Bis[6-15,6dihydrochelerythrinyl)] ether was the most active of the tested compounds with mean $\mathrm{IC}_{50 \text { s }}$ of $14.9 \pm 1.4 \mu \mathrm{M}$ in FCM29 strain and $15.3 \pm 3.4 \mu \mathrm{M}$ in 3D7 strain $(\sim 58$ to $\sim 1130$ times less active than chloroquine respectively). The anti-Plasmodium activities of the tested alkaloids of $Z$. rubescens were low; and do not encourage the use of this plant as antimalarial.

KEY WORDS : Zanthoxylum rubescens, Rutaceae, alkaloids, amides, bis[6(5,6-dihydrochelerythrinyll)] ether, malaria. dihydrochelerythrinyl)] ether; and two amides: zanthomamide and 3D7 strain and the chloroquine-resistant FCM29 strain of

Résumé : FAIBLE ACTIVITÉ ANTIPLASMODIALE DES ALCALOÏDES ET AMIDES ISOLÉS DE L'ÉCORCE DE TIGE DE ZANTHOXYLUM RUBESCENS (RUTACEAE)

Zanthoxylum rubescens (syn. Fagara rubescens) est utilisée en médecine traditionnelle pour traiter la fièvre associée au paludisme en Côte d'Ivoire. Trois alcalö̈les ( $N$-nornitidine, 7,9-dimethoxy2,3-methylenedioxybenzophenanthridine et bis[6-15,6dihydrochelerythrinyl)] ether), et deux amides (zanthomamide et lemairamide) isolés de l'écore de tige de cette plante ont été testés in vitro pour évaluer leurs activités sur deux souches de Plasmodium falciparum. Les résultats obtenus ont montré que $N$ nornitidine est inactive et que l'activité antiplasmodiale de 7,9dimethoxy-2,3-methylenedioxybenzophenanthridine, lemairamide et zanthomamide, est faible avec des Cl50 de 45,6 $\mu \mathrm{M}$ à 149,9 $\mathrm{M}$. Bis[6-(5,6-dihydrochelerythrinyl)] ether a été la plus active parmi les cing molécules testées, cependant avec des moyennes de Cl50 à 14,9 $\pm 1,4 \mu \mathrm{M}$ contre la souche P. falciparum FCM29 (résistante à la chloroquine) et de 15,3 3 3,4 $\mu \mathrm{M}$ contre la souche P. falciparum 3D7 (sensible à la chloroquine). Bis[6-(5,6-dihydrochelerythrinyl)] ether est ainsi de 58 à 1130 fois moins actif que la chloroquine. Cette étude montre que l'activité anti-Plasmodium de ces alcaloïdes et amides de Z. rubescens ne justifie pas son utilisation de cette plante comme antipaludique.

MOTS CLÉS : Zanthoxylum rubescens, Rutaceae, alcaloïdes, amides, bis[6-15,6dihydrochelerythrinyll] ether, paludisme.

used as toothache remedy (Fish et al., 1974), or to prevent abortion in pregnant women (Penali, personal communication). Since bitter compounds such as alkaloids have shown antiplasmodial activity (Addae-Kyereme et al., 2001; Andrade-Neto et al., 2003; Kassim et al., 2005; Randrianarivelojosia et al., 2003; Sener et al., 2003), we isolated and assessed the in vitro antiplasmodial properties of alkaloids and amides from, $Z$. rubescens. The purpose of the investigation was to identify the schizonticidal effects of these compounds against

\footnotetext{
* Malariology Department, Institut Pasteur de Côte d'Ivoire, 01 BP 490 Abidjan 01, Ivory Coast.

** Natural Products Research Group, School of Chemistry, University of KwaZulu-Natal, Durban, 4041, South Africa.

**:* Department of Chemistry, Egerton University, P.O. Box 536-20107, Njoro, Kenya.

**:** Malaria Research Group, BP 1274, Antananarivo (101), Institut Pasteur de Madagascar, Madagascar.

**:*** School of Biomedical and Molecular Sciences, University of Surrey, Guildford, Surrey, GU2 7XH, United Kingdom.

Correspondence: Milijaona Randrianarivelojosia.

Tel.: +261202241272 - Fax: +261202241534.

E-mail: milijaon@pasteur.mg
}

P. falciparum.

\section{MATERIALS AND METHODS}

\section{PLANT MATERIAL}

The stem bark of Zanthoxylum rubescens Planch. Ex. Hook f. (syn. Fagara rubescens Engl.) (Rutaceae) was collected from the Lamto forest in the 
central part of Ivory Coast at the beginning of the rainy season in May 2004. Plant identification was confirmed by Professor Aké Assi by comparison with authentic specimens at the "Centre National de Floristique" of the University of Cocody, Abidjan, Ivory Coast where a voucher specimen was retained (TK023/04).

\section{CHEMICAL ANALYSIS}

Air dried, milled stem bark of Zanthoxylum rubescens (562.6 g) was extracted successively with hexane, dichloromethane, ethyl acetate and methanol in a Soxhlet apparatus for 24 hours with each solvent. Isolation and purification of compounds from the crude extracts were performed using gravity column chromatography over silica gel (Merck Art. 9385). Thin layer chromatographic analysis was carried out on $0.2 \mathrm{~mm}$ silicagel, aluminium-backed plates (Merck Art. 5554) and spots were visualized under UV light and then by spraying with anisaldehyde spray reagent followed by heating. The hexane extract was separated using a hexane/ethyl acetate solvent mixture (85/15); the dichloromethane extract was separated with a dichloromethane/methanol (99/1) solvent mixture while the methanol extract was separated using a dichloromethane/methanol mixture (97/3). Low resolution mass spectra were obtained on Agilent GC MS 5975 instrument and ${ }^{1} \mathrm{H}$ and ${ }^{13} \mathrm{C}$ NMR spectra were recorded on a Varian Unity Inova 400 MHz NMR spectrometer. Optical rotations were measured at room temperature in chloroform using a Perkin-Elmer 241 polarimeter with a $10 \mathrm{~cm}$ flow tube. IR spectra were recorded with a Nicolet Impact 400 D spectrometer on sodium chloride plates and calibrated against an air background. UV spectra were obtained on a Varian DMS 300 UVvisible spectrometer.

\section{IN VITRO ANTIMALARIAL TESTING}

Test compounds were dissolved in methanol/water 50:50 in the presence of citric acid to make up a stock solution of $6.4 \mathrm{mg} / \mathrm{ml}$. Serial dilutions were made in distilled water to obtain needed solutions. Test compounds were applied to culture plates which were dried under the hood before testing. The final dilution contained less than $16 \mu \mathrm{g} / \mathrm{ml}$ of citric acid, which had no measurable effect on parasite survival in this system. Samples were tested in 96-well plates in triplicate at final concentrations of $64,16,8,4,2$, and $0.5 \mu \mathrm{g} / \mathrm{mL}$. Tests were performed three times for each compound. Chloroquine diphosphate (Sigma Chemical, St Louis, MO, USA) was used as a control.

3D7 (chloroquine-sensitive) and FCM29 (chloroquineresistant) strains of Plasmodium falciparum were cultured in a gas mixture containing $5 \% \mathrm{CO}_{2}, 5 \% \mathrm{O}_{2}$, and $90 \% \mathrm{~N}_{2}$ at $37^{\circ} \mathrm{C}$ according to the Trager and Jensen method (Andrianantenaina et al., 2002; Trager \& Jensen
1976). The culture medium RPMI 1640 (Gibco-BRL Laboratories, Grand Island, USA), supplemented with $10 \%$ heat-inactivated human type $\mathrm{AB}^{+}$serum (Abcys, Chausson, Paris), $25 \mathrm{mM} \mathrm{NaHCO}_{3}, 2 \mathrm{mM}$ glutamine and 25 HEPES (Sigma, St. Louis, MO, USA) was used. Parasites cultures were maintained in type $\mathrm{O}^{+}$human red blood cell suspensions obtained from healthy local donors (Centre of Blood Transfusion, Military Hospital, Antananarivo, Madagascar).

The in vitro antiplasmodial tests were performed using the isotopic method (Desjardins et al., 1979; Randrianarivelojosia et al., 2002). The cultured malaria parasites were synchronized by use of D-alanine (BraunBreton et al., 1988). Parasitemia was adjusted at $0.5 \%$ by adding non-infected type $\mathrm{O}^{+}$non-infected red blood cells. P. falciparum-containing red blood cells were suspended in the complete RPMI 1640 medium with $10 \%(\mathrm{v} / \mathrm{v}) \mathrm{AB}^{+}$human serum at $1.5 \%$ hematocrit. In vitro testing was performed in 96-well plates $(200 \mu 1$ parasite suspension per well). Parasite growth was assessed by adding tritium labelled hypoxanthine at $1 \mu \mathrm{Ci}$ per well (Amersham Bioscience, Saclay, France) to the culture medium. Plates were incubated at $37^{\circ} \mathrm{C}$ for 42 hours in a humidified modulator incubator chamber MIC-101 (Billups-Rothenberg, Del Mar, California, USA) flushed with a gas mixture containing $5 \% \mathrm{CO}_{2}$, $5 \% \mathrm{O}_{2}$, and $90 \% \mathrm{~N}_{2}$. Afterward, plates were frozen and then defrosted, and each well was harvested onto fiberglass paper (Wallac ${ }^{\circledR}$, Turkey, Finland). The incorporated tritium labelled hypoxanthine was determined using a beta counter (Wallac 1450, Turkey, Finland). Growth curves were obtained, and the $50 \%$ inhibitory concentration $\left(\mathrm{IC}_{50}\right)$ values were calculated by use of a log-probit approximation (Randrianarivelojosia et al., 2002). The $\mathrm{IC}_{50} \mathrm{~S}$ were converted from $\mu \mathrm{g} / \mathrm{ml}$ into $\mu \mathrm{M}$. The Students' t test was used for statistical comparison between mean $\mathrm{IC}_{50} \mathrm{~s}$. The difference was considered significant for $P$ values under 0.05 . To target promising antiplasmodial compounds, we considered plant extracts with IC50 values $>64 \mu \mathrm{g} / \mathrm{ml}$ as "inactive".

\section{RESULTS AND DISCUSSION}

Dive known compounds were isolated from the $\checkmark$ stem bark of Zanthoxylum rubescens. The struc_ tures were determined using NMR spectroscopy and MS and confirmed by comparison against literature data as 7,9-dimethoxy-2,3-methylene dioxybenzophenanthridine (Sukari et al., 1999) (3.4 mg), N-nornitidine (Martin et al., 2005) (6.8 mg) isolated from the hexane extract; zanthomamide $(88.2 \mathrm{mg})$, lemairamide (5.0 mg) (Adesina \& Reisch 1989; Adesina et al., 1997; Simeray et al., 1985) isolated from the dichloromethane extract; bis[6-(5,6-dihydrochelerythrinyl] ether (Dostal et al., 1995) $(6.6 \mathrm{mg})$ isolated from the methanol extract. 


\begin{tabular}{lrr}
\hline \multicolumn{1}{c}{ Compounds from Z. rubensens } & \multicolumn{2}{c}{ Mean IC $_{\mathbf{5 0}}$ in $\mathbf{\mu M}$} \\
\cline { 2 - 3 } & on 3D7 & on FCM29 \\
\hline Bis[6-(5,6-dihydrochelerythrinyl)] ether & $15.3 \pm 3.4$ & $14.9 \pm 1.4$ \\
7,9-Dimethoxy-2,3-methylenedioxybenzophenanthridine & $72.2 \pm 13.5$ & $92.4 \pm 41.9$ \\
Lemairamide & $89.7 \pm 22.7$ & $101.1 \pm 18.7$ \\
Zanthomamide & $133.8 \pm 98.6$ & $149.9 \pm 59.5$ \\
N-nornitidine & inactive & inactive \\
Chloroquine diphosphate (control) & $0.014 \pm 0.008$ & $0.256 \pm 0.037$ \\
\hline
\end{tabular}

Table I. - In vitro response of the chloroquine-sensitive 3D7 and chloroquine-resistant FCM29 strains of Plasmodium falciparum to Z. rubescens compounds.

The $\mathrm{IC}_{50}$ values obtained from testing the various compounds against $P$. falciparum are summarized in Table I. $\mathrm{N}$-nornitidine was found to be inactive; 7,9-dimethoxy2,3-methylenedioxybenzophenanthridine, and the amides lemairamide and zanthomamide showed mild antiplasmodial activity. Bis[6-(5,6-dihydrochelerythrinyl)] ether (Fig. 1) was found to be the most active of the alkaloids tested against $P$. falciparum in vitro. The $\mathrm{IC}_{50}$ value for bis[6-(5,6-dihydrochelerythrinyl)] ether on the chloroquine-resistant strain FCM29 (mean IC $_{50}=14.9 \pm$ $1.4 \mu \mathrm{M})$ was not significantly different from the $\mathrm{IC}_{50}$ value against the chloroquine-sensitive strain $3 \mathrm{D} 7$ (mean $\left.\mathrm{IC}_{50}=15.3 \pm 3.4 \mu \mathrm{M}\right)$. Bis[6-(5,6-dihydrochelerythrinyl)] ether was $\sim 58$ to $\sim$ 1,130 times less active than chloroquine respectively against FCM29 and against 3D7 strains. In comparison with the chloroquine activity against $P$. falciparum in our study and in comparison with the activity of the benzophenanthridine alkaloid fagaronine from Fagara zanthoxyloides against $P$. falciparum with a mean $\mathrm{IC}_{50}$ at $18 \mathrm{ng} / \mathrm{ml}$ as reported (Kassim et al., 2005), the anti-Plasmodium activities of the tested alkaloids of $Z$. rubescens were moderate. Nevertheless, both chloroquine-sensitive and chloroquine-resistant strains of $P$. falciparum were similarly affected by the $Z$. rubescens alkaloid bis[6-(5,6-dihydrochelerythrinyl)] ether.

Although the mechanism of action of bis[6-(5,6-dihydrochelerythrinyl)] ether is unknown, we suggest that<smiles></smiles>

Fig. 1. - Chemical structure of bis[6-(5,6-dihydrochelerythrinyl)] ether. it does not act via the chloroquine pathway. Bis[6-(5,6dihydrochelerythrinyl)] ether should be investigated further to discover compounds that act against chloroquine-resistant parasites. Traditional medicine practices are based on the treatment of clinical symptoms. Antimalarial plants such as Zanthoxylum species are principally used to treat fever although fever may be caused by various infectious pathogens including malaria parasites, viruses or bacteria.

\section{ACKNOWLEDGEMENTS}

W e are grateful to Mr D. Jagjivan for running NMR spectra. Antiplasmodial in vitro testing was undertaken by Dr M.A. Rason and $\mathrm{Mr}$ $\mathrm{H}$. Andrianantenaina. Mr O. Lassina helped in plant collection. This work was supported by the National Research Foundation (NRF) in South Africa, by the French Government via the project FSP/RAI and by the Institut Pasteur.

\section{REFERENCES}

Addae-Kyereme J., Croft S.L., Kendrick H. \& Wright C.W. Antiplasmodial activities of some Ghanaian plants traditionally used for fever/malaria treatment and of some alkaloids isolated from Pleiocarpa mutica; in vivo antimalarial activity of pleiocarpine. Journal of Ethnopharmacology, 2001, 76, 99-103.

Adesina S.K., Olugbade T.A., Akinwusi D.D. \& Willert D.J. New Amides from Zanthoxylum lemairie pericarps. Planta Medica, 1997, 63, 286-287.

AdEsINA S.K. \& ReISCH J. Amides from Zanthoxylum rubescens. Phytochemistry, 1989, 28, 839-842.

Andrade-Neto V.F., Brandao M.G., Stehmann J.R., Oliveira L.A. \& Krettli A.U. Antimalarial activity of Cinchona-like plants used to treat fever and malaria in Brazil. Journal of Ethnopharmacology, 2003, 87, 253-256.

ANDRIANANTENAINA H.B., RANDRIANARIVElojosia M. \& Jambou R. Effet du surnageant de culture primaire d'hépatocytes de souris sur la prolifération in vitro des isolats sauvages de Plasmodium falciparum. Archives de l'Institut Pasteur de Madagascar, 2002, 68, 68-72. 
Braun-Breton C., Rosenberry T.L. \& Da Silva L.P. Induction of the proteolytic activity of a membrane protein in Plasmodium falciparum by phosphatidyl inositol-specific phospholipase C. Nature, 1988, 332, 457-459.

Desjardins R.E., Canfield C.J., Haynes J.D. \& Chulay J.D. Quantitative assessment of antimalarial activity in vitro by a semiautomated microdilution technique. Antimicrobial Agents Chemotherapy, 1979, 16, 710-718.

Dostal J., Taborska E., Slavik J., Potacek M. \& Hoffmann E. Structure of chelerythrine base. Journal of Natural Products, 1995, 58, 723-729.

Fish F., Gray A. \& Waterman P. Further constituents from the root bark of Zanthoxylum rubescens. Planta Medica, 1974, 25, 281-284.

Kassim O.O., Loyevsky M., Elliott B., Geall A., Amonoo H. \& GoRDEUK V.R. Effects of root extracts of Fagara zanthoxyloides on the in vitro growth and stage distribution of Plasmodium falciparum. Antimicrobial Agents Chemotherapy, 2005, 49, 264-268.

Martin M.T., Rasoanaivo L.H. \& Raharisololalao A. Phenanthridine alkaloids from Zanthoxylum madagascariense. Fitoterapia, 2005, 76, 590-593.

Randrianarivelojosia M., Ariey F., Raharimalala L.A., Parzy D., Rogier C. \& JAmbou R. Current absence of pyrimethamine resistance of Plasmodium falciparum in Madagascar. Transactions of the Royal Society of Tropical Medicine and Hygiene, 2002, 96, 557-559.

Randrianarivelojosia M., Rasidimanana V.T., Rabarison H., Cheplogoi P.K., Ratsimbason M., Mulholland D.A. \& MauCLERE P. Plants traditionally prescribed to treat tazo (malaria) in the eastern region of Madagascar. Malaria Journal, 2003, 2, 25.

Sener B., Orhan I. \& Satayavivad J. Antimalarial activity screening of some alkaloids and the plant extracts from Amaryllidaceae. Phytotherapy Research, 2003, 17, 12201223.

Simeray J., Chaumont J.P., Bevalot F. \& Vaquette J. Zanthomamide: an aromatic amide from Zanthoxylum thomense. Phytochemistry, 1985, 24, 2720-2721.

Sukari M.A., Salim W.S.W., Ibrahim N.H., Rahmani M., Aimi N. \& Kiтаjima M. Phenanthridine alkaloids from Zanthoxylum myriacanthum. Fitoterapia, 1999, 70, 197-199.

TRAgE W. \& JENSEN J.B. Human malaria parasites in continuous culture. Science, 1976, 193, 673-675.

Reçu le 18 décembre 2006 Accepté le 17 janvier 2007 